$$
\begin{gathered}
\text { 種々のアルキルアミンで有機化したモンモリロナイト添加による } \\
\text { アクリルゴムの高性能化 }{ }^{\dagger}
\end{gathered}
$$

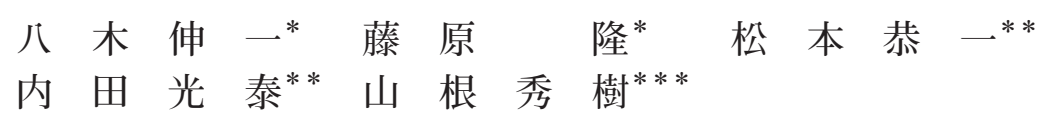

\title{
High Performance Elastomer Composed of the Acrylic Rubber Filled with Montmorillonite Organically Treated with Various Alkyl Amines
}

\author{
by \\ Shinichi Yagi ${ }^{*}$, Takashi FujIwara ${ }^{*}$, Kyoichi Matsumoto ${ }^{*}$, \\ Mitsuyasu UchidA ${ }^{* *}$ and Hideki Yamane ${ }^{* * *}$
}

\begin{abstract}
Montmorillonites organically treated with various alkylamines were filled to the acrylic rubber and various properties including mechanical, oil resistance, and abrasion were investigated. Montmorillonite tended to exfoliate after the organic treatment and uniformly dispersed in the acrylic rubber. This uniform dispersion of the filler resulted in the improvement of the mechanical property. Number of carbon atoms in the alkylamine used for the organic treatment increased the swelling with oil at high temperature. Abrasion wear rate of the acrylic rubber was reduced when organically treated montmorillonite was well dispersed in the matrix.
\end{abstract}

Key words : Nanocomposites, Elastomer, Montmorillonite, Mechanical property, Exfoliation

\section{1 緒言}

近年, 高性能, 高機能化の要求の高まりを背景にして, ゴム材料に強度, 弾性, 而油性, 而熱性など各種物性の 向上が求められている。このため, 従来から, ゴムにフィ ラーを配合して, ゴム材料の物性を向上させることが行 われている. パッキン, シールといった各種ゴム製品に 対しては, 耐熱性, 弾性, 耐油性, 耐候性が必要とされ, 従来, 非ジエン系ゴムであるアクリルゴム, シリコーン ゴム, ウレタンゴム等が採用されている。これらの非ジ エン系ゴムで作成されたパッキン, シール材に高性能化, 高機能化の要求が高まるに伴い, 機械的強度等の物性の 向上が求められ, 特に弾性特性の向上が強く求められて いる。ゴムを含む樹脂製品に打いて，これら諸性質を改 善するために, ナノサイズを有する無機フィラーとポリ マーとの複合体（ポリマーナノコンポジット）の研究が 盛んに行なわれている.1) 8)最も実用化が進んでいるのが, 厚さ約 $1 \mathrm{~nm}$ の結晶が積層された層状結晶構造を有する モンモリロナイト，へクトライト等のスメクタイト（膨 潤性粘土鉱物）を充填したナノコンポジットである。層 状構造を有するスメクタイトを高分子中にナノサイズレベ ルまではく離分散させることにより, 従来の補強性フィ ラーよりもはるかに少量の添加で力学的性質の向上が達 成されるとともに著しい軽量化を図ることができる.9) 12) 我々の以前の研究では, 溶融混練によりアクリルゴムに
種々の有機化処理を施したモンモリロナイトを充填した ナノコンポジットの調整を行ったが, 溶融混練では粘度 の非常に高いアクリルゴム中にモンモリロナイトが均一 分散せず, 弾性率は増大したものの, 強度, 破壞伸び, 破壊エネルギーは低下した. ${ }^{12)}$ 本研究では, ポリマー中に おけるモンモリロナイトのナノレベルでの均一分散を目 指し, 溶液混合によりナノコンポジットを調製，モンモ リロナイトの処理方法, 充填率が種々の力学的性質に与 える影響について検討した。

\section{2 実験}

\section{$2 \cdot 1$ 試料}

マトリックスとして，アクリル酸エチルを主モノマー， 架橋点モノマーを 2-Chloroethyl vinyl ether とするアク リルゴム $(\mathrm{ACM})(\mathrm{AR} 71$ ：日本ゼオン) を用いた。架橋 鼡として 2,4,6-trimercapto-s-triazine, 架橋促進剤として tetrabuthylthiuram disulfide を用いた。層状粘土鉱物の モンモリロナイト (MMT) は高純度 MMT (P.G.W：ボ

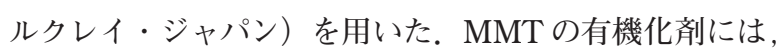
アルキル鎖炭素数が 12 のラウリルアミン (LUA) および, アルキル鎖炭素数が 18 のステアリルアミン (STA) (ナカ ライテスク）を用いた。

\section{$2 \cdot 2$ MMT の有機化}

$80^{\circ} \mathrm{C}$ の温水 $80 \mathrm{ml}$ に MMT $2 \mathrm{~g}$ を加え, ホモジナイザー (AM-5：日本精機製作所）を用い，5000rpm で 10 分間

$\dagger$ 原稿受理 平成 20 年 5 月 12 日 Received May 12, 2008 @ 2009 The Society of Materials Science, Japan

* 京都工芸繊維大学大学院工芸科学研究科 T606-8585 京都市左京区松ヶ崎海道町, Graduate School of Sci. and Tech., Kyoto Inst. of Tech., Sakyo-ku, Kyoto, 606-8585

** 中西金属工業(株) †530-8566 大阪市北区天満橋, Nakanishi Metal Works Co., Ltd., Kita-ku, Osaka, 530-8566

*** 正 会 員 京都工芸䋊維大学繊維科学センター $=606-8585$ 京都市左京区松ヶ崎海道町, Center for Fiber and Textile Sci., Kyoto Inst. of Tech., Sakyo-ku, Kyoto, 606-8585 
かく拌した. MMTを分散させた後, アミン $2.8 \mathrm{mmol}$ と $6 \mathrm{~N} \mathrm{HCl} 6 \mathrm{ml}$ を含む $80^{\circ} \mathrm{C}$ に調整した蒸留水 $40 \mathrm{ml}$ を加え， さらに $5000 \mathrm{rpm}$ で $80^{\circ} \mathrm{C}, 10$ 分間かく拌した。固形物を濾 別し, 温水で 3 回洗浄した。回収物を乾燥し, 有機化 MMTを得た。 以降, ラウリルアミン処理 MMTをLUAMMT, ステアリルアミン処理 MMT を STA-MMT と略す.

\section{$2 \cdot 3$ 溶液混合によるナノコンポジットの調製}

所定量の MMT をトルエン／ $\mathrm{MeOH}=40 / 2$ (vol/vol) の混合溶液に加え，一時間かく找した後， $20 \mathrm{wt} \%$ の ACM を加え一晚かく拌した。この混合溶液に ACM $100 \mathrm{wt} \%$ に 対し，架橋剂 $2.45 \mathrm{wt} \%$ ，架橋促進剤 $1 \mathrm{wt} \%$ を加え 1 時間か く拌した。この後，真空乾燥機にて脱気を行い，シャー レにキャストし乾燥させることによりキャストフィルム

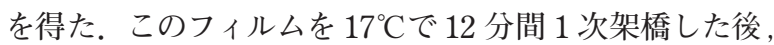
$160^{\circ} \mathrm{C} て ゙ 4$ 時間熱プレスすることにより 2 次架橋させ，厚 さ $1 \mathrm{~mm}$ のシート状試料を得た。

\section{$2 \cdot 4$ 測定および観察}

MMT の IR 測定は FTIR (FTIR-8200PC：SHIMADZU) により，400 $\mathrm{cm}^{-1}$ から $4000 \mathrm{~cm}^{-1}$ の範囲で $\mathrm{KBr}$ 錠剤成型 法により作製した試料を用いて測定した。 MMT，およ び ACM/MMTナノコンポジットシートの広角 X 線回折 (WAXD) 強度分布は，広角 X 線回折装置 (RINT-2100FLS：Rigaku）を用いて測定した。管電圧 $40 \mathrm{kV}$ ，管電 流 $30 \mathrm{~mA}$ で $\mathrm{Ni}$ フィルターした $\mathrm{CuK} \alpha$ 線 $(\lambda=0.1542 \mathrm{~nm})$ を照射し, $2 \theta=2^{\circ} \sim 10^{\circ}$ の範囲で測定した。微粒子分散 状態は, SEM (VE-7800：KEYENCE) により観察した。 試料には金蒸着を施した。試料の力学的性質は引張試 験機（CATY500BH：米倉製作所）により測定した。 $\mathrm{ACM} / \mathrm{MMT}$ ナノコンポジットシートから打ち抜いたダ ンベル型試験片（3 号）を引張試験用試料とし，チャッ ク間距離 $10 \mathrm{~mm}$, 引張速度 $100 \mathrm{~mm} / \mathrm{min}$, 室温で行った. 動的粘弾性の温度依存性は UBM Rheogel-E4000 を用い て測定した。シートから $25 \mathrm{~mm} \times 5 \mathrm{~mm}$ の短冊状試料を 切り出し, 引張モード，チャック間距離 $15 \mathrm{~mm}$, 昇温速 度 $3^{\circ} \mathrm{C} / \mathrm{min}$ ，測定周波数 $16 \mathrm{~Hz}$ とし， $0.07 \%$ の伸長ひず みを与えて温度範囲-50 $100^{\circ} \mathrm{C}$ で測定した。耐油性は， テストチューブ式熱老化試験機（東洋精機製作所）を用 い，試料の初期体積と $150^{\circ} \mathrm{C}$ オイル（IRM903）に70 時間浸漬後の体積を水中置換法にて測定し，それらの体 積変化から評価した。摩耗試験は摩耗試験機（中西金属 工業）を用いて行い，試料を $100 \mathrm{rpm}$ で回転する金属製 の摩耗板表面に荷重 $200 \mathrm{~g}$ で 120 秒間接触させた際の摩 耗高さを測定した。

\section{$3 \cdot 1$ 各種クレイの赤外分光分析}

Fig. 1 に未処理 MMT および有機化処理 MMTの IR スペクトルを示す．有機化処理を行った MMTでは， $2850 \mathrm{~cm}^{-1}$ および $2920 \mathrm{~cm}^{-1}$ 付近に未処理 MMT では見ら れない C-H 伸縮振動によるピークが確認できる。また， $3250 \mathrm{~cm}^{-1}$ 付近の N-H 伸縮振動, $790 \mathrm{~cm}^{-1}$ 付近の N-H 変 角振動などの存在により，有機化処理が確認できる。な お，LUA-MMT と STA-MMT の間には大きな差異は認め られなかった。

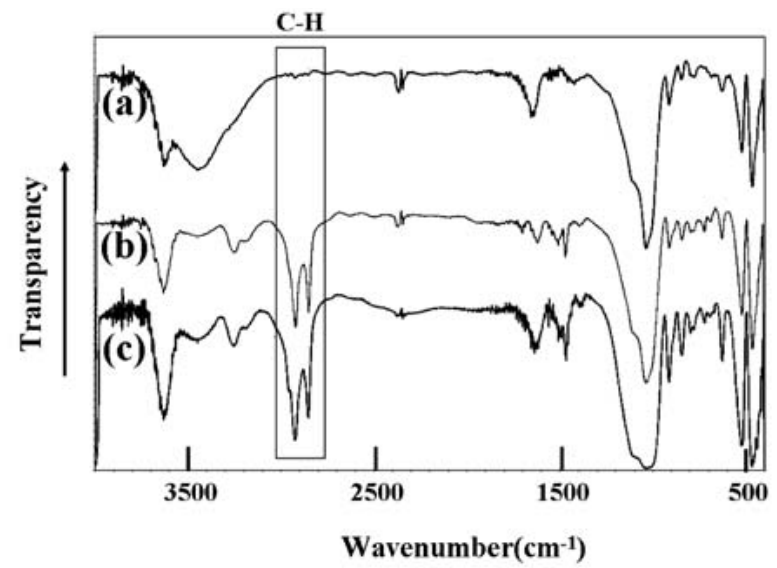

Fig. 1 IR spectra of (a) untreated MMT, (b) laurylamine treated MMT, and (c) stearylamine treated MMT.

\section{$3 \cdot 2$ 有機化処理 MMT の構造と MMT の分散性}

Fig. 2 にMMTの WAXD 強度分布を示す。未処理 MMT は $2 \theta=6.8^{\circ}$ にブロードな反射ピークを示しており， ピークの $2 \theta$ から層間距離は $\mathrm{d}=1.30 \mathrm{~nm}$ となり, MMT の層間距離についての文献值 ${ }^{13)} 2 \theta=6.84^{\circ}(\mathrm{d}=1.29 \mathrm{~nm})$ と 一致する。一方, LUA-MMT は $2 \theta=3.7^{\circ}$, STA-MMT は $2 \theta=5.6^{\circ}$ に反射ピークを示し，層間距離はそれぞれ $\mathrm{d}=$ $2.64 \mathrm{~nm}, \mathrm{~d}=3.27 \mathrm{~nm}$ となる。このことより有機化処理 により MMT 層間へアルキルアミンが導入され，層間距 離が広がったことが明らかである。

Fig. 3 に未処理 MMT，および有機化処理 MMTの SEM 写真を示す。未処理 MMT は, 無定形の塊状微粒 子であり，層状構造は確認できない。一方，有機化処理 MMT ははく片化していることが確認できる。

Fig. 4 にACM/MMT シート断面の SEM 写真を示す. 未処理 MMT は混合前と比較するとややサイズが小さい ものの凝集状態でマトリックス中に包埋されている。一 方，有機化処理 MMT は，薄片化，分散しており， STAMMT 添加試料ではわずかに小さな塊状粒子が観察され たが，LUA-MMT 添加試料では塊状物は観察されず，良 好な分散性を示していた。

Fig. 5 にMMTを $5 \mathrm{wt} \%$ 添加した ACM/MMT シート の WAXD 強度分布を示す。未処理 MMT 充填試料では

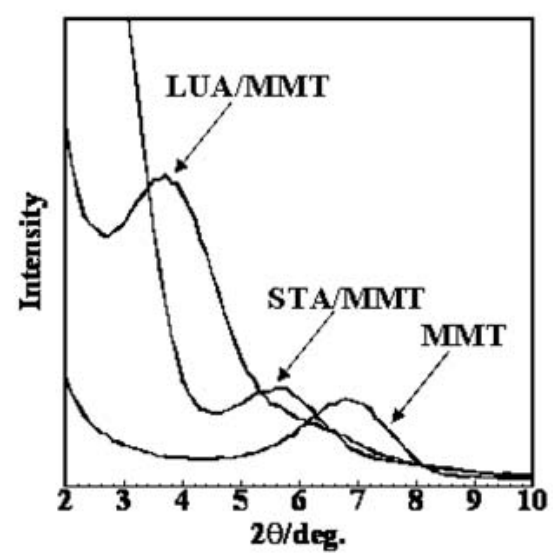

Fig. 2 WAXD patterns of MMT and organically treated MMTs. 

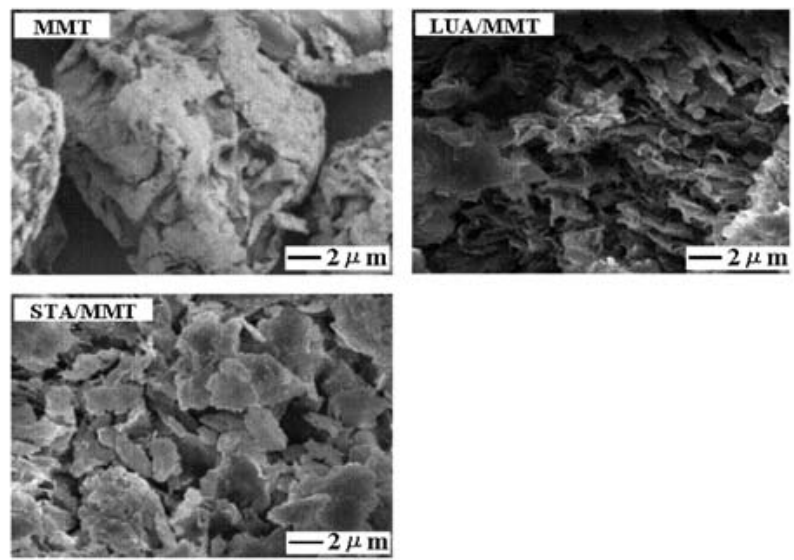

Fig. 3 SEM micrographs of MMT and organically treated MMTs.
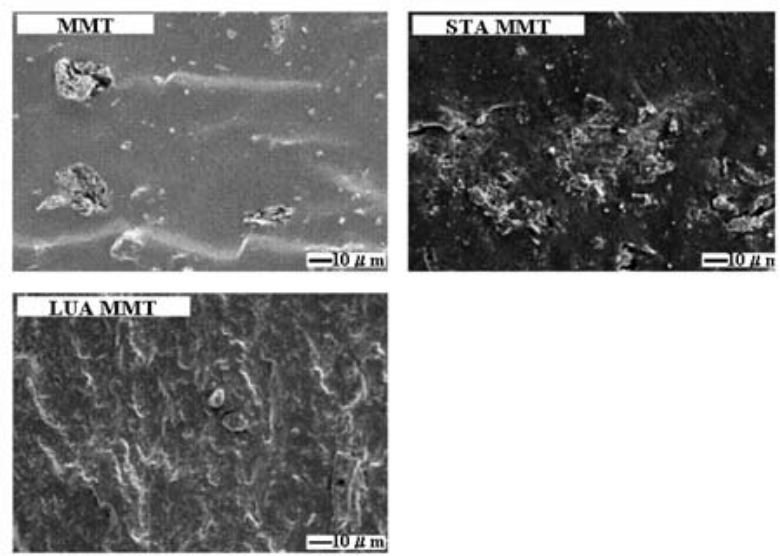

Fig. 4 SEM micrographs of ACM filled with untreated MMT, laurylamine treated MMT, and stearylamine treated MMT.

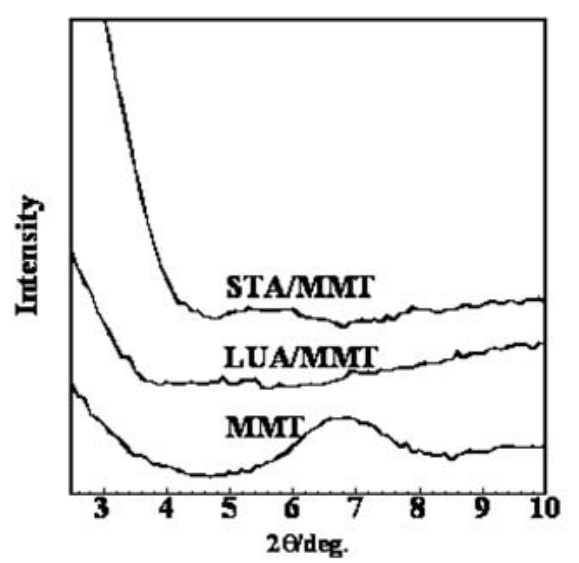

Fig. 5 WAXD pattern of ACM/MMT nanocomposites.

$2 \theta=6.8^{\circ}$ 付近の反射が明白に観察されるが，有機化処 理 MMT を充填した ACM/MMTシートでは，層状 MMT 由来のピークは明白には観察されないが，STAMMT 添加試料では STA-MMT で観察された $2 \theta$ 付近に ブロードなピークが確認できる。これらのことより，有 機化 MMT は, MMT の層が剥離した状態でマトリック ス中に分散しているが, STA-MMT はわずかに層構造を
維持しているように思われる。一方，未処理 MMTは， Fig. 4 の SEM 画像からも示されたように，はく離分散 は起きていないため層構造由来の反射が観察されたもの と思われる。

\section{$3 \cdot 3$ 架橋試料の力学的性質}

ACM/MMTナノコンポジットシートの, MMT 添加量 に伴う力学的性質の変化を Fig. 6 に示す. 未処理 MMT 充填試料では, 引張強度と破壊伸びは MMT 添加量に伴 いわずかに上昇しているが, 弾性率はほとんど変化して いない。また，MMT添加による破壊エネルギーの増加 もわずかであった。一方，有機化処理 MMT 添加試料で は, MMT の添加量に伴い強度, 弾性率共に大きく増加 しており，それに伴い破壊エネルギーも著しい増加を示 した。また，破壞伸びは $5 \mathrm{wt} \%$ の MMT 添加量までは大 きく上昇しているが，それ以上の添加量では MMT 無添 加試料より高いもののやや低下している。 これの結果は, すでに示した有機化处理 MMT の剥片化と良好な分散を 反映しているものと考えられる。しかしながら，有機化 処理 MMTを添加した試料でも，添加量の増大と共に MMT が疑集し始め，マトリックスと MMT 凝集物の界 面付近にボイドが発生することにより破壊伸びの低下と なったものと考えられる。 LUA-MMT 添加試料と STAMMT 添加試料とを比較すると, 弾性率に大きな差は見 られないが，強度と破壊エネルギーは LUA-MMT 添加試 料の方が高くなった。これは，SEM 観察打よびWAXD 分布強度から明らかなように, 有機化处理 MMT は剥片 化しているものの, STA-MMT は若干の凝集構造と層構 造を維持していることによるものと思われる.

\section{$3 \cdot 4$ 架橋試料の動的粘弾性}

ACM/MMTナノコンポジットの動的粘弾性を Fig. 7 に示す。低温領域では, どの試料も高い貯蔵弾性率 E’を 示しており, ACM のガラス転移温度以下では ACM の七 グメントが凍結されているため MMT 添加量打よび有機 化处理の影響はほとんど見られない. $\mathrm{E}^{\prime} は-10^{\circ} \mathrm{C}$ 付近から 低下し始め, $40^{\circ} \mathrm{C}$ 付近以上で再び一定値に達している. それに伴い, $\tan \delta$ は $5 \sim 10^{\circ} \mathrm{C}$ 付近にピークを示してい る. 未处理 MMT 添加試料では $\mathrm{E}^{\prime}, \tan \delta$ の值およびピー ク温度はMMT の充填率に依存していない。一方, 有機 化处理 MMT 添加試料では, MMTの充填率の影響が明 白に現れている。ガラス転移温度付近での E’の低下量と $\tan \delta$ ピーク高さは MMT の添加量と共に小さくなり，ま た, $\tan \delta$ のピーク温度は MMT 添加量と共にわずかに低 温側にシフトしている。室温付近の E'は同じ MMT 添加 量で比較すると, LUA-MMT 添加試料が最も高く, 未処 理 MMT 添加試料が最も低くなっている。これは室温で 測定した引張弾性率の結果と一致している.

\section{$3 \cdot 5$ 摩耗特性}

平均摩耗高さは MMT 無添加試料が $0.06 \mathrm{~mm}$ であった のに対し，10wt\%LUA-MMT 添加試料では $0.01 \mathrm{~mm}$ とな り, 有機化処理 MMT の添加により耐摩耗性が向上して いる。これは，有機化 MMT がマトリックス中に均一分 散することにより，ACM 摩擦接触面が一様に MMT で 

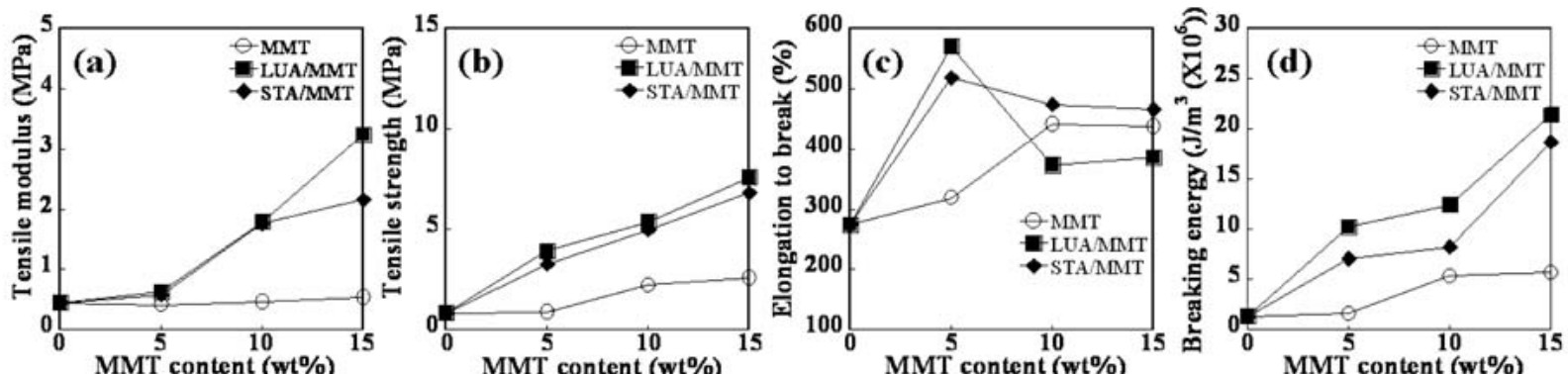

Fig. 6 Mechanical property of ACM filled with untreated and alkylamine treated MMTs. (a) Tensile modulus, (b) tensile strength, (c) elongation to break, and (d) breaking energy.
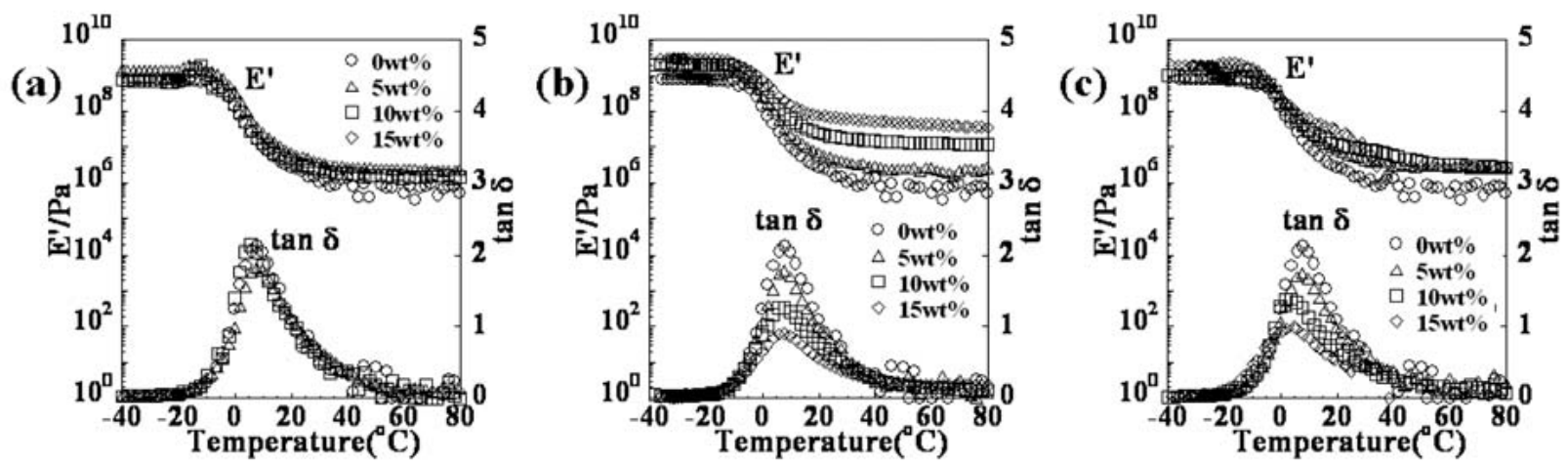

Fig. 7 Temperature dependence of the storage modulus G' and $\tan \delta$ of ACM filled with the untreated and alkylamine treated MMTs. (a) Untreated MMT/ACM, (b) Laurylamine treated MMT/ACM, and (c) Stearylamine treated MMT/ACM.

保護される形となり，マトリックスに加わる摩擦を軽減 し，耐摩耗性を向上させたものと考えられる，残念なが ら, MMT 無添加試料およびLUA-MMT 添加試料以外で は摩擦試験に供することが可能な表面を持つ試料が作成 できなかったため, MMTの分散状態の影響は検討でき なかった。

\section{$3 \cdot 6$ 耐油性}

Fig. 8 に有機化 MMT 添加試料の体積変化率と MMT 添加量との関係を示す。なお，未処理 MMT 添加試料は 凝集した MMT を含んでいるため，再現性のある結果が 得られなかった。 LUA-MMT 添加試料の体積変化は MMT 添加量に依存せず, MMT 無添加試料と同等の值 を示した。一方, STA-MMT添加試料では，体積変化率 は添加率の増加とともに大きく増大した。このことより，

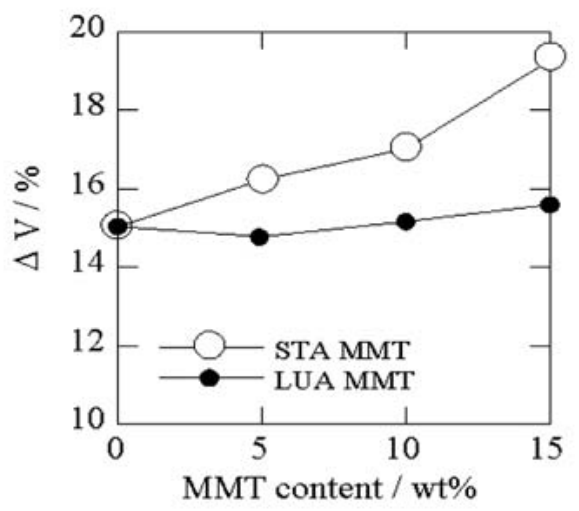

Fig. 8 Volume changes of ACM filled with MMT at various contents.
アルキルアミン炭素数が増加すると, 高温度のオイルに よる膨潤が著しくなる事が分かった.

\section{4 結 言}

層状鉱物である MMT に有機化処理を施すことにより， MMTの薄片化がなされ，アクリルゴム中での均一分散 に伴い強度, 弾性率および破壊エネルギーなどの力学的 性質が向上することが分かった。未処理 MMT がはく離 せず，分散性が悪かったのに対し，有機化処理 MMTで ははく片化と分散性を示した。特にLUA-MMT は ACM マトリックス中で最も良好なはく片化と分散性を示した。

有機化に用いたアミンのアルキル基炭素数が多くなる と, 高温のオイルの膨潤性が高まる傾向があり, 有機化 剤により耐油性も大きく影響する事が分かった。また耐 摩耗性は良好に分散した MMTにより向上し, ACM/ MMTナノコンポジットは力学的性質以外にも，耐油性 や，耐摩耗性といった機能的付加価值を持つことが分 かった。

\section{参 考 文 献}

1) A. Samakande, P. C Hartmann, V. Cloete and R. D. Sanderson, "Use of acrylic based surfmers for the preparation of exfoliated polystyreneeclay nanocomposites”, Polymer, Vol.48, Issue 6, pp.1490-1499 (2007).

2 ) S. Filippi, E. Mameli and C. Marazzato, "Comparison of solution-blending and melt-intercalation for the preparation of poly (ethylene-co-acrylic acid)/organoclay Nanocomposites", European Polymer Journal, Vol.43, Issue 5, pp.1645-1659 (2007). 
3 ) J. Ma, J. Xu, J.-H. Ren, Z.-Z. Yu and Y.-W. Mai, “A new approach to polymer/montmorillonite nanocomposites”, Polymer, Vol.44, pp.4619-4624 (2003).

4 ) M. Arroyo, M. A. Lo'pez-Manchado and B. Herrero, "Organomontmorillonite as substitute of carbon black in natural rubber compounds", Polymer, Vol.44, pp.2447-2453 (2003).

5 ) M. Xu, Y. S. Choi, Y. K. Kim, K. H. Wang and I. J. Chang, "Synthesis and characterization of exfoliated poly (styreneco-methylmethacrylate)/clay nanocomposites via emulsion polymerization with AMPS”, Polymer, Vol.44, pp.6387-6395 (2003).

6 ) K. G. Gatos and J. Karger-Kocsis, "Effect of the aspect ratio of silicate platelets on the mechanical and barrier properties of hydrogenated acrylonitrile butadiene rubber (HNBR) /layered silicate nanocomposites”, European Polymer Journal, Vol.43, Issue 4, pp.1097-1104 (2007).

7 ) R. Valsecchi, M. Vigano and M. Levi, "Dynamic Mechanical and Rheological Behavior of Fluoroelastomer- Organoclay Nanocomposites Obtained from Different Preparation Methods”, Journal of Applied Polymer Science, Vol.102, Issue 5, pp.4484-4487 (2006).
8 ) I. Kelnar, V. Khunova, J. Otek and L. Kapralkova, "Effect of clay treatment on structure and mechanical behavior of elastomer-containing polyamide 6 nanocomposite”, Polymer, Vol.48, Issue 18, pp.5332-5339 (2007).

9) M. Y. Choi, S. Anandhan and J. H. Youk, "Synthesis and Characterization of In Situ Polymerized Segmented Thermoplastic Elastomeric Polyurethane/Layered Silicate Clay Nanocomposites”, Journal of Applied Polymer Science, Vol.102, Issue 3, pp.3048-3055 (2006).

10) S. Balakrishnan, P. R. Start, D. Raghavan and S. D. Hudson, "The influence of clay and elastomer concentration on the morphology and fracture energy of preformed acrylic rubber dispersed clay filled epoxy nanocomposites”, Polymer, Vol.46, Issue 25, pp.11255-11262 (2005).

11) W.-G. Hwang, K.-H. Wei and C.-M. Wu, "Preparation and mechanical properties of nitrile butadiene rubber/silicate nanocomposites”, Polymer, Vol.45, pp.5729-5734 (2004).

12) S. Yagi, T. Fujiwara, H. Yamane, K. Matsumoto and M. Uchida, "Preparation and properties of elastmeric nanocomposites", Proceedings of the 18th Kobunnshi Kakou Toronkai, p.20 (2006). 